\title{
Using different epilithic-diatom assemblage metrics for an ecological characterization of the shores of Lake Garda
}

\author{
Daniel SPITALE, Alessia SCALFI, Horst LANGE-BERTALOT ${ }^{1)}$ and Marco CANTONATI* \\ Museo delle Scienze, Limnology and Phycology Section, Via Calepina 14, I-38122 Trento, Italy \\ ${ }^{1)}$ Institute for Ecology, Evolution, Diversity, University of Frankfurt, Siesmayerstraße 70, and Senckenberg Research Institute, \\ Senckenberganlage 31-33, D-60054 Frankfurt/M., Germany \\ *e-mail corresponding author: cantonati@mtsn.tn.it
}

\begin{abstract}
It has been proved that littoral diatoms provide a useful marker for detecting localised changes resulting from uneven anthropogenic disturbances or intermittent releases of sewage along the shorelines of lakes. This study tested the spatial resolution at which this general observation occurs, by selecting areas with different anthropogenic pressures (urbanization) along a latitudinal gradient in Lake Garda, a deep and wide peri-Alpine lake. The sampling design aimed to detect differences in diatom distribution in terms of species diversity, quality indices, proportion of Red List taxa, assemblages, and individual species. Because the extent to which diatom assemblages respond to these gradients was unknown, we used assemblage metrics of different sensitivities. Results showed that the most important environmental factor was the latitudinal gradient, which was revealed by almost all the assemblage metrics. This dominant trend was explained by two co-occurring environmental gradients: concentration of nutrients and thermal gradient. The importance of different levels of urbanization was unevenly partitioned among locations and latitudes because of the different intensities of urbanization pressure. Only the species Brachysira neglectissima, the quality index (Trophic Index), and to a lesser extent, the metric at assemblage level revealed significant effects. Overall, this study comes to two main conclusions: (1) different metrics are needed to detect the multifaceted effects of anthropogenic disturbances, which by their very nature are unevenly distributed and of different intensities, and therefore affect assemblages to different degrees; (2) for any monitoring program in this lake to be effective, the various gradients revealed in this work should be taken into account. Failing to include these sources of variability might lessen the benefits of monitoring.
\end{abstract}

Key words: Benthic diatoms, lake littoral, trophic status, ecological status, Italy

\section{INTRODUCTION}

Diatoms are an abundant, diverse and important component of algal assemblages in freshwater lakes. They are able to respond rapidly to environmental variations like eutrophication and recovery (Smol \& Stoermer 2010), because they are sensitive to changes in nutrient concentrations and ratios (Tilman et al. 1982). Diatoms are increasingly used to assess water quality because they are good indicators of the trophic and ecological status of lakes (Stenger-Kovács et al. 2007). Although there has been a considerable amount of work using diatoms to monitor river water quality in Europe (e.g., Whitton \& Rott 1996; Prygiel et al. 1999) there are still proportionally few studies of their use in lake monitoring (King et al. 2006). Many studies have shown that diatoms from littoral areas can reliably indicate different environmental gradients (Douglas \& Smol 1995; King et al. 2000; Lim et al. 2001; Schönfelder et al. 2002). Because some indices based on littoral diatoms (Hofmann 1994; Kelly et al. 2006; StengerKovács et al. 2007) are cost-effective proxies for 'phytobenthos' (Kelly 2006), they have now also been applied within the Water Framework Directive 2000/60/EC (Council of the European Communities 2000).
One topic that has still not been examined in any detail is the sensitivity of littoral diatoms to environmental gradients within the same lake. Preliminary studies have suggested that assessments of littoral diatoms at a fine spatial scale might be useful in evaluating specific trophic states and variations along the shores of lakes (e.g., point-pollution sources analyzed by Poulíčková et al. 2004).

The first floristic studies of littoral phytobenthos in Lake Garda date back to the nineteenth century, at which time they reported a diatom richness of 135 species (Schröter \& Kirchner 1896; Garbini 1897; 1899a, b; Forti 1899; Kirchner 1899). Although Lake Garda is one of the most important central European lakes, after those early floristic studies no more reports on littoral diatoms were published. The shores of Lake Garda are highly urbanized due to the increasing population and the particular importance of tourism (Chiaudani \& Premazzi 1990). In spite of this high anthropogenic pressure and the long theoretical water renewal time ( $c a 27$ years), the lake has maintained a reasonable water quality until recently (Büsing 1998). However, the lake shows a slight but continuous increase of total phosphorus concentrations, representing the last stage of a longterm process of enrichment that has been documented since the 1970s (Mosello \& Giussani 1997; Salmaso 
2009). The local effects of eutrophication are mainly restricted to the near-shore areas because of a diffuse use of the terrain (Büsing 1998). However, although insufficiently documented, a latitudinal trophic gradient might also be present, due mainly to an input of nutrients by the northern inflow and by the uneven distribution of the urbanized areas.

This study has focused on the ecological characterization of the shores of Lake Garda by studying epilithic littoral diatoms. An array of samples covering different gradients (urbanization pressure and latitudinal) were chosen for our consideration. As the extent to which diatom assemblages respond to these gradients is unknown, we used assemblage metrics of different sensitivities. Diversity indices might be considered to be the most general metrics because they take advantage only of the number of taxa and different proportions (Magurran 2004). Although data are far from satisfactory because of the variation found, there is a general tendency for species diversity to decrease with the increasing fertility of the water (Smol \& Stoermer 2010). A second family of metrics, thought to be more sensitive in detecting gradients, are the quality indices (e.g., Barbour et al. 2000). By their very nature, quality indices are likely to be more sensitive because they are weighted according to species preferences. In this study, the quality indices used, which are based on littoral and epilithic diatoms, are those developed for European lakes (Hofmann 1994; Kelly et al. 2006). In studies of diatom assemblages, Red List information has been increasingly used (Werum \& Lange-Bertalot 2004; Cantonati \& Spitale 2009). In some cases, the proportion of endangered taxa included in the Red List for central Europe (Lange-Bertalot 1996) was better able than other assemblage metrics (like Shannon diversity) to illustrate the different distributions observed among the sites (Werum \& Lange-Bertalot 2004). The use of Red List taxa here is motivated by the fact that endangered or rare species can be expected to have a more restricted niche breadth compared to the most common species, so the proportion of rare or endangered species may be sensitive enough to reveal even minor differences between affected and unaffected sites. The effect of anthropogenic disturbances might also occur at the level of the whole diatom assemblage; in this case, a similarity index might enable the proportional variation of the species to be successfully detected. Finally, the same disturbances might affect the abundance of individual species. Although it might be difficult to select in advance which species would be more sensitive, this could be a sound way to identify potential indicator species calibrated for Lake Garda. This paper therefore has two main aims: (1) to describe and quantify the variation in epilithic diatom assemblages among shores with different urbanization pressures and along a latitudinal gradient, and (2) to verify the extent of these supposed gradients by using different assemblage metrics.

\section{METHODS}

\subsection{Study area}

Lake Garda (65 m a.s.1.) is the largest Italian lake with a surface area of $368 \mathrm{~km}^{2}$, a volume of $49 \mathrm{~km}^{3}$, and a maximum depth of $346 \mathrm{~m}$. The lake has one important inlet (Sarca), located at the northern edge and other less important tributaries flowing towards the western and northern shores. Littoral zones are not throughout homogeneous: in the narrow part rocky and steep shores dominate, while on the wide, southern part the shores are more gradual, and composed mainly by sand and cobbles. Regardless of the shore localization, many urbanized areas include both hard substratum (especially around ports and dockings) and sandy littorals. Urbanization is also unevenly distributed around the lake according to the more or less steep slope of the interior areas.

\subsection{Sampling procedure}

An observational experiment (sensu Underwood 1997) including a combination of three treatments was planned and executed in one week on September 2008 along the rocky shores of Lake Garda. Since the lake extending north-south, three main portions were distinguished along the latitude (North, Centre, South) separated by at least $7 \mathrm{~km}$ (Fig. 1); within each portion, two random locations were selected, with two levels of urbanization (low and high urbanization) each one replicated twice.

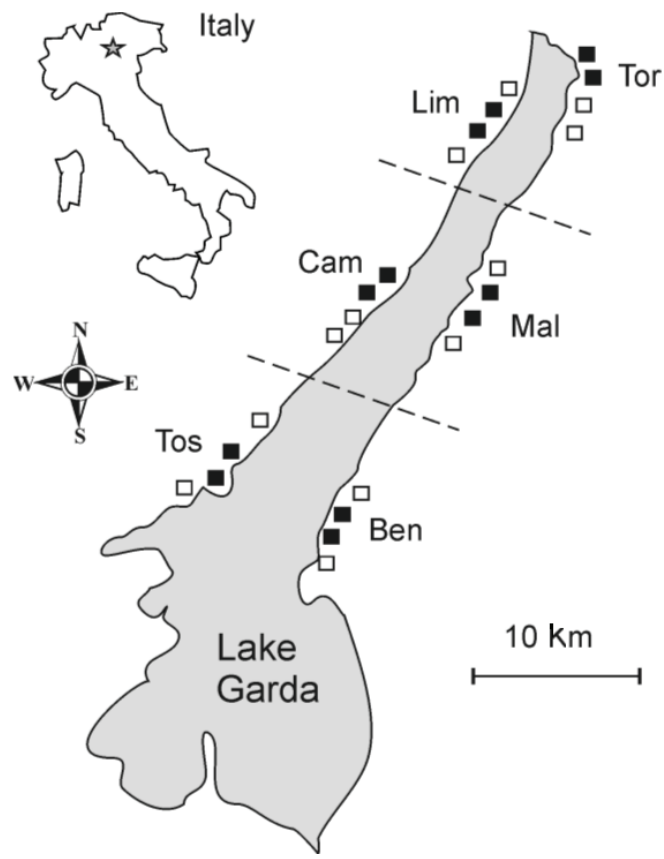

Fig. 1. Map showing the position of sampling stations. North, Centre and South locations are delimited by dashed lines (two locations on each latitude level). Filled and empty squares are high and low urbanized areas. Locations are: at North Torbole and Limone, at Centre Malcesine and Campione, at South Benaco and Toscolano. 
The levels high and low of the treatment urbanization were selected respectively in and out urbanized areas. In contrast to low-urbanized, highlyurbanized areas were characterized by high density of urban settlements with intense use of the shores (ports, boats, wastewater etc). Only areas with hard substratum were selected for sampling. The wide, south portion of the lake (Fig. 1), after careful survey, was discarded because it did not provide the hard substrata requested for this sampling design. Locations were selected at random within each latitude but balancing the east and west coast. With this sampling design we tested the following hypotheses on the diatom assemblages: (1) no difference among latitudes pooling urbanization treatments; (2) no difference between urbanizations, pooling latitudes; (3) no interaction between latitudes and urbanization; (4) no added variance due to the localities within latitudes; (5) no interaction between urbanization and the locations within latitude.

Epilithic diatoms were sampled at one meter depth (that level never emerged in the last 12 months) by means of a special brushing syringe $\left(\right.$ area $\left.=5.31 \mathrm{~cm}^{2}\right)$; the brush plunger was pulled down rotating and aspiring at the same time. Three circular areas were brushed in three different points 3-5 meters apart for a total investigated area of $15.93 \mathrm{~cm}^{2}$.

For each sampling station we estimated slope and heterogeneity of the shore at two spatial scales. At fine spatial scale, slope was measured by means of a clinometer $20 \mathrm{~cm}$ long, whereas at coarse scale the slope was estimated trigonometrically measuring the depth at 4 meters off the coastline. Heterogeneity at fine spatial scale was estimated by a profile gauge (length $=17 \mathrm{~cm}$; grain $=112$ needles) which was pulled down to the rocky surface; then the device was photographed, the digital imagine processed to measure its profile length and heterogeneity was expressed as the ratio between profile and profile gauge (so that values $=1$ indicate homogeneity, values $>1$ heterogeneity). Heterogeneity at coarse spatial scale was estimated by using a metal chain $5.2 \mathrm{~m}$ long (grain $=260$ rings) which was laid down on the rocky surface; then, the distance between the extremities was measured, and heterogeneity was expressed as above. Within a regular plot $1-\mathrm{m}$ wide, at a depth ranging between 1 and $4 \mathrm{~m}$, the different proportions of the substratum were visually estimated separating the following classes: \% of sand and gravel (size $<6 \mathrm{~cm}), \%$ of cobbles $(6-24 \mathrm{~cm})$, and $\%$ of stones and rocks $(>24 \mathrm{~cm})$. On each sampling station we retained the average class of three replicated plots 3-5 metres apart.

Finally, in the 24 sampling stations, we collected in acid cleaned bottles the water for the hydrochemical analyses (which included the measurement of $\mathrm{pH}$, conductivity, and nutrients) following the standards provided by the American Public Health Association (APHA 2000).

\subsection{Diatom identification and quantification}

The field samples were treated with hydrogen peroxide and hydrochloric acid to remove respectively organic material and carbonates; then the cleaned valves were mounted in Naphrax ${ }^{\circledR}$. Three permanent mounts were prepared for each sample, and a total of 600 valves were counted to assess relative abundances. To determine the diatom abundance as number of individuals we used DVB (divinylbenzene) spheres with a mean diameter of $c a 6 \mu \mathrm{m}$. Slides, prepared material, and aliquots of the original samples were deposited in the diatom collection of the Museo Tridentino di Scienze Naturali (Accession numbers: cLIM005 DIAT1302-1325). Counting was optimized with a Zeiss Axioskop 2 at $1000 \times$ magnification while identification and nomenclature followed Krammer \& Lange-Bertalot (19861991, 2004), Round et al. (1990), Round \& Bukhtiyarova (1996), Lange-Bertalot (1993), Lange-Bertalot \& Moser (1994), Lange-Bertalot \& Metzeltin (1996), Krammer (1997a, b), Reichardt (1997, 1999), LangeBertalot (2001), Krammer (2002/2003), Werum \& Lange-Bertalot (2004), and Levkov (2009).

\subsection{Data analyses}

Data were analysed with 3 mixed factor analysis of variance: latitude (three levels, fixed), locations (2 levels within latitude; random), urbanization (two levels, fixed) crossed with latitude and the interaction of location within latitude; with $\mathrm{n}=2$ replicate samples (total = 24 samples). Non-significant sources of variation were pooled only if the $p$ level was at least $=0.25$ (Underwood 1997). Cochran's C-test was used to check the assumption of homogeneity of variances before using ANOVA in tests of hypotheses. The diatom response to the treatments was determined by calculating (1) the diversity indexes (Shannon $\log _{2}$, Margalef, Pielou, Brillouin, Simpson; see Magurran 2004); (2) the quality indexes by Hofmann (1994) and by Kelly et al. (2006); (3) the number of Red List taxa (Lange-Bertalot 1996); (4) the response for each single species; (5) the response at assemblage level. For the first four metrics, three-way ANOVAs were calculated. With the proportion of Red List taxa we mean the sum of rare and endangered diatoms as reported by Lange-Bertalot (1996) plus some unpublished integrations by one of us (H.L.B.). The same ANOVA model was applied for the environmental variables collected along with diatom samples.

To examine differences in the multivariate context of species assemblages, we used the same procedure as described for the univariate analysis but using a distance-based multivariable analysis of variance (Anderson 2001). In addition, the significance of the treatment latitude at assemblage level was tested controlling the nutrient concentration by using a multivariate ANCOVA. To calculate the amount of variance in the assemblage data explained by the environmental vari- 
ables (slope and micro-macroheterogeneity; substratum textures; hydrochemicals) we applied a redundancy analysis (RDA, Legendre \& Legendre 1998). RDA was preferred over CCA because of the short gradient of our data (result not showed). The best subset of environmental variables was selected by using an improved method of the classical forward selection (Blanchet et al. 2008). Then, only the significant terms were retained and processed in the RDA. Assemblage data was transformed using the Hellinger method because it is particularly suited for the RDA (Legendre \& Gallagher 2001).

A non-metrical multidimensional scaling (NMDS) with a Bray-Curtis similarity index was used to order and visualize the samples (Legendre \& Legendre 1998). Univariate ANOVAs were performed using STATISTICA 8 (Statsoft, Inc), whereas multivariate analyses were done with R (R Development Core Team 2009) loading the package vegan $\mathrm{v} 1.15-4$ (Oksanen et al. 2009).

\subsection{Quality indexes}

In this study, the Trophic Index (Hofmann 1994) and the Lake Trophic Diatom Index (Kelly et al. 2006) were applied because considered to be most suited, taking into due account the bathymetric characteristics of the lake and its rocky shores. The Hofmann metric, as it was conceived, provides a score which increases with the trophic status (high values on worse quality status). The Kelly et al. index, being an ecological quality ratio, results in high values when the quality is high. A possible way to test which of the two indices is more suited to Lake Garda, would be to correlate their scores to the nitrate contents of water. A positive and a negative correlation between index scores and nitrate was expected respectively for the Hoffman and the Kelly et al. index.

\section{RESULTS}

Environmental variables associated to each diatom sample provided additional insights to the experimental factors used. Total phosphorus (mean $=8 \mu \mathrm{g} \mathrm{L}^{-1}$, min$\max =5-14$ ) but even more clearly nitrate concentration $\left(\right.$ mean $\left.=0.42 \mathrm{mg} \mathrm{L}^{-1}, \min -\max =0.17-0.68\right)$, showed a significant decrease towards south whereas the effect of urbanization was not revealed consistently at all the latitudes (Fig. 2; the term Lat for the TP was significant after pooling, Tab. 1). TP showed heterogeneous variance and its significance should be interpreted with caution. Geogenic variables did not show any significant trend because they were nearly constant in all samples. Among the physical variables, significantly higher values of microheterogeneity were found in the lowurbanized areas (once the non significant terms were pooled, Fig. 2). Substratum composition was not significantly different after ANOVA analyses.

In total, 75 diatom taxa belonging to 29 genera were found. Eight species were found in all samples:
Achnanthidium affine (Kützing) Czarnecki, A. minutissimum (Kützing) Czarnecki, Cymbella excisa var. angusta Krammer, Encyonopsis krammeri Reichardt, E. subminuta Krammer \& Reichard, Fragilaria capucina ssp. austriaca (Grunow) Lange-Bertalot, Navicula cryptotenelloides Lange-Bertalot, $N$. subalpina Reichardt.
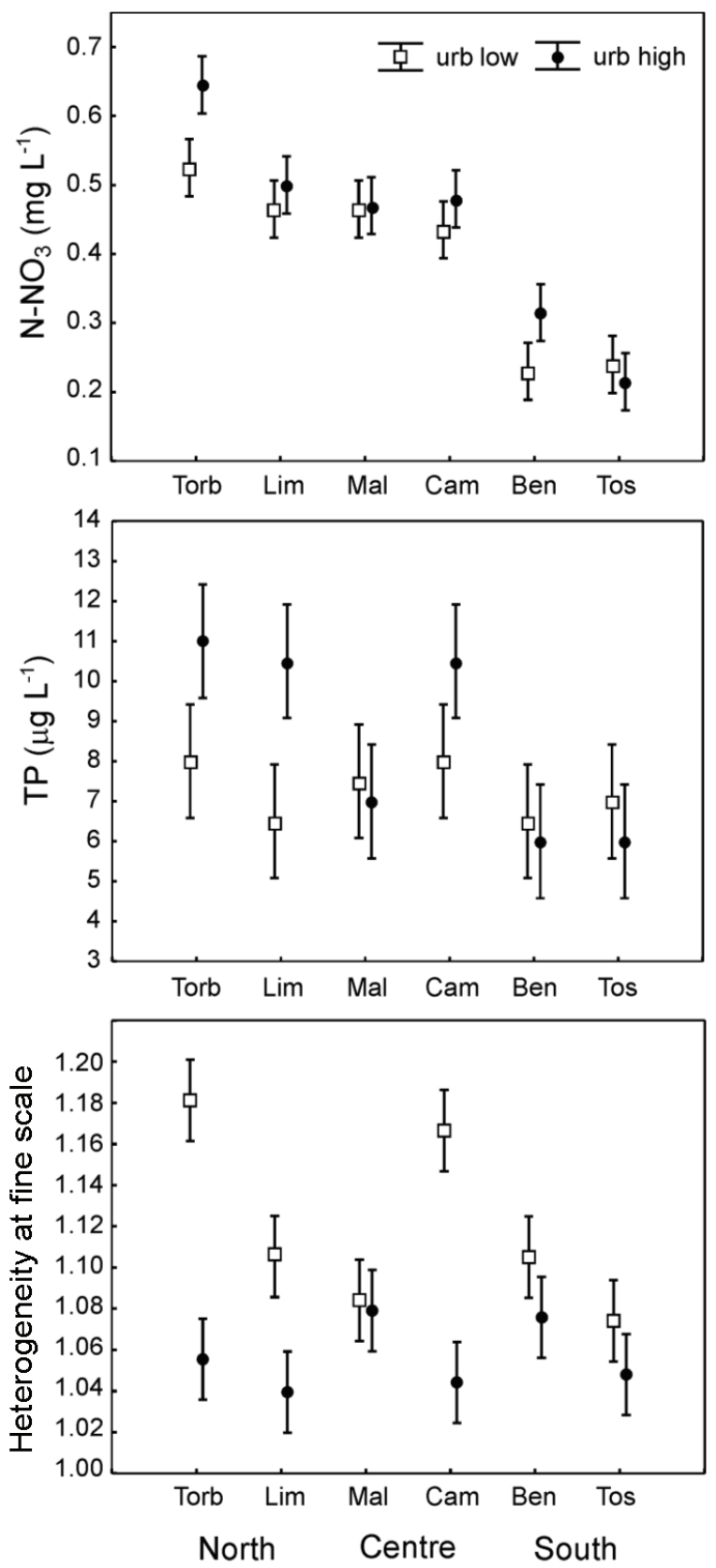

Fig. 2. Some of the most significant environmental descriptors measured in the sampling stations of Lake Garda: nitrate concentration $\left(\mathrm{N}-\mathrm{NO}_{3}\right)$, total phosphorus (TP) and microheterogeneity. Bars are standard errors.

The complete list of species, average abundances on the main treatments and Red List taxa are given in the Appendix 1. Diversity indexes were not different among 
Tab 1. Univariate ANOVAs comparing urbanization (Urb), latitude (Lat) and location (Loc) for three environmental variables, total phosphorus (TP), nitrate $\left(\mathrm{N}_{-} \mathrm{NO}_{3}\right)$ and microheterogeneity. Hypothesis of homogeneity of variances (after Cochran's C-test) was rejected for TP. Probabilities of relevant tests are indicated in bold. * significant term $(p<0.05)$ after post hoc pooling.

\begin{tabular}{|c|c|c|c|c|c|c|c|c|c|c|}
\hline \multirow[b]{2}{*}{ Source } & \multirow[t]{2}{*}{$d f$} & \multicolumn{3}{|c|}{ TP } & \multicolumn{3}{|c|}{$\mathrm{N}-\mathrm{NO}_{3}$} & \multicolumn{3}{|c|}{ microheterogeneity } \\
\hline & & MS & $\mathrm{F}$ & $p$ & MS & $\mathrm{F}$ & $p$ & MS & $\mathrm{F}$ & $p$ \\
\hline Urb & 1 & 9.375 & 5.488 & 0.101 & 0.012 & 3.356 & 0.164 & 0.023 & 8.080 & 0.065 \\
\hline Lat & 2 & 14.625 & 4.333 & $0.130^{*}$ & 0.174 & 20.702 & 0.018 & 0.001 & 0.400 & 0.703 \\
\hline Loc(lat) & 3 & 3.375 & 0.835 & 0.500 & 0.008 & 2.468 & 0.112 & 0.002 & 3.027 & 0.071 \\
\hline Urb*Lat & 2 & 9.125 & 5.341 & 0.103 & 0.002 & 0.481 & 0.659 & 0.002 & 0.800 & 0.525 \\
\hline Loc(Lat)Urb & 3 & 1.708 & 0.423 & 0.740 & 0.003 & 1.022 & 0.417 & 0.003 & 3.710 & 0.043 \\
\hline Residual & 12 & 4.042 & & & 0.003 & & & 0.001 & & \\
\hline
\end{tabular}
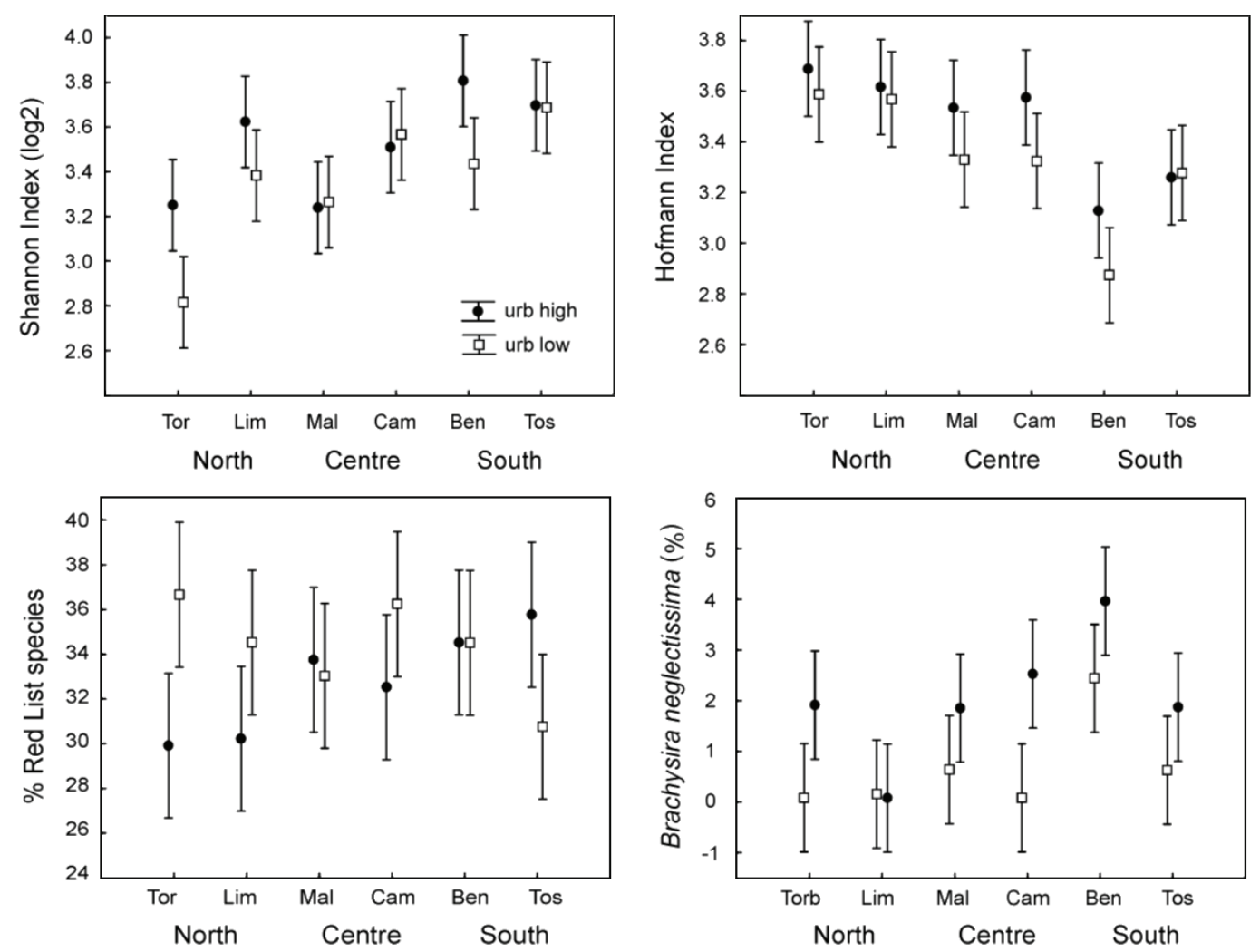

Fig. 3. Effects of urbanization and latitude on the diatom assemblage metrics. Bars are standard errors.

treatments even though they tended to increase towards the south latitude. Because all the 5 diversity indexes showed very similar results, from now on we presented only Shannon, motivated only by its popularity (Fig. 3). Diatom diversity was not affected by urbanization but it tended to increase in the southern locations (Tab. 1). However, the Pearson correlation between diversity and nitrate concentration was negative and significant $(r=$ $-0.46 ; p=0.02$ ).

Application of the Hofmann index provided a general mean $=3.40$ corresponding to a mesotrophic condition, but some locations were evaluated as belonging to the meso-eutrophic class $(\min -\max =2.71-3.88)$. The Kelly et al. index, giving a mean $=0.82($ min-max $=$ 0.53-1.04), suggested a condition of good quality, but with samples predicted as moderate and high quality. Correlation between Hofmann and Kelly was unexpectedly positive and significant $(r$ Pearson $=0.51 ; p=$ $0.011)$ suggesting inconsistent results. To test which of the two indices might be more suited to Lake Garda, we correlated them with the nitrate concentrations: Kelly and $\mathrm{N}_{-} \mathrm{NO}_{3}(r=0.48 ; p=0.018)$; Hofmann and $\mathrm{N}-\mathrm{NO}_{3}$ $(r=0.64 ; p<0.001)$. Because the Hofmann Index outperformed the Kelly et al. index, subsequent analyses considered only the former (remember that a negative correlation was expected between Kelly and nitrate, see the methods section). The proportion of species unavailable in the original publication by Hofmann (1994) but recorded in the present study, was not correlated with the score index $(r=0.09 ; p=0.683)$. Out of the 75 spe- 
Tab. 2. Univariate ANOVAs comparing urbanization (Urb), latitude (Lat) and location (Loc) for biological metrics on the original, not transformed data. Hypothesis of homogeneity of variances (after Cochran's C-test) was not rejected. Probabilities of relevant tests are indicated in bold.

\begin{tabular}{|c|c|c|c|c|c|c|c|c|c|c|c|c|c|}
\hline \multirow[b]{2}{*}{ Source } & \multirow[b]{2}{*}{$d f$} & \multicolumn{3}{|c|}{ Shannon } & \multicolumn{3}{|c|}{ Red List } & \multicolumn{3}{|c|}{ Hofmann (1994) } & \multicolumn{3}{|c|}{ B. neglectissima } \\
\hline & & MS & $F$ & $p$ & MS & $F$ & $p$ & MS & $F$ & $p$ & MS & $F$ & $p$ \\
\hline Urb & 1 & 0.158 & 5.664 & 0.098 & 13.580 & 1.610 & 0.294 & 0.119 & 9.056 & 0.057 & 11.169 & 12.778 & 0.038 \\
\hline Lat & 2 & 0.314 & 1.531 & 0.348 & 2.990 & 1.324 & 0.387 & 0.473 & 9.613 & 0.050 & 5.606 & 1.833 & 0.302 \\
\hline Loc(Lat) & 3 & 0.205 & 2.453 & 0.114 & 2.262 & 0.108 & 0.134 & 0.049 & 0.699 & 0.571 & 3.058 & 1.342 & 0.307 \\
\hline Urb*Lat & 2 & 0.073 & 2.622 & 0.220 & 32.353 & 3.835 & 0.149 & 0.012 & 0.945 & 0.481 & 0.456 & 0.522 & 0.640 \\
\hline Loc(Lat)Urb & 3 & 0.028 & 0.334 & 0.801 & 8.441 & 0.402 & 0.754 & 0.013 & 0.186 & 0.904 & 0.874 & 0.384 & 0.767 \\
\hline Residual & 12 & 0.084 & & & 20.980 & & & 0.070 & & & 2.279 & & \\
\hline
\end{tabular}

Tab 3. Permutational MANOVA on the basis of the Bray-Curtis dissimilarities matrix. Each test was based on 999 permutations. Urb = urbanization, Lat = latitude, Loc $=$ locality.

\begin{tabular}{lccccc}
\hline Source & $d f$ & SS & MS & $F$ & $p$ \\
\hline Urb & 1 & 947.9 & 947.9 & 1.697 & 0.142 \\
Lat & 2 & 2644.4 & 1322.2 & 1.387 & 0.211 \\
Loc(Lat) & 3 & 2860.2 & 953.4 & 2.179 & $\mathbf{0 . 0 0 6}$ \\
Urb*Lat & 2 & 847.6 & 423.8 & 0.759 & 0.705 \\
Loc(Lat)Urb & 3 & 1676.3 & 558.8 & 1.278 & 0.194 \\
Residual & 12 & 5251.6 & 437.6 & & \\
\hline
\end{tabular}

cies recorded during this work, 55 were available $(73 \%)$. The index decreased significantly towards the south latitude discriminating between urbanization levels at a $p$ level $=0.057$ (Fig. 3; Tab. 2).

The proportion of Red List taxa was not significantly affected by the treatments even after post hoc pooling (Tab. 2). However, focussing only on those locations where the TP was significantly higher in the urbanized areas (Torbole, Limone and Campione, Fig. 3), endangered species were significantly less abundant.

Assemblage data ordered by means of NMDS (Fig. 4) and analyzed by permutational multivariate analysis of variance indicated a significant interaction Loc (Lat) (Tab. 3).

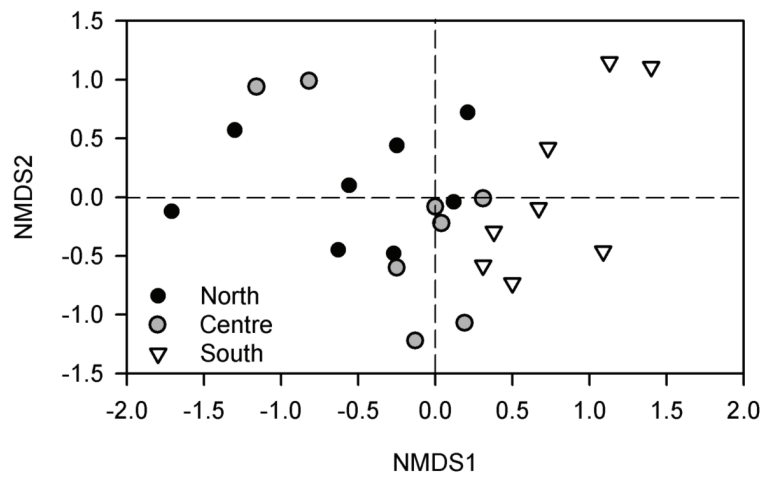

Fig. 4. Diagram of the nonmetrical multidimensional scaling (NMDS) based on Bray Curtis similarity matrix of the diatom assemblages. Stress values $=0.18$.

This result suggested that the assemblages were strongly driven by which of the random levels "location" was considered. However, even though this result did no change its significance after the post hoc pooling, a clear difference was appreciable between the south latitude and the centre- north (Fig. 4). Low and high urbanization levels were revealed by the assemblages only when the differences in nitrate concentration between the two were appreciable (Torbole, Limone, Campione and Benaco; Fig. 2). Selecting these samples, and simplifying the model retaining only the urbanization factor, the difference resulted clearly significant $(F=2.96 ; p=0.012)$. The ANCOVA analysis performing by controlling the effect of the nutrient contents, revealed a residual significant effect of latitude on the diatom assemblages $(F=1.62 ; p=0.048)$. Forward selection run to select the most important environmental variables for the assemblage distribution, indicated a significant role of slope at broad scale, silicate and nitrogen concentration, and microheterogeneity (Tab. 4). Redundancy analysis performed by using only these significant variables was highly significant $(F=$ 3.05; $p<0.001)$ and explained a high amount of the total variance $(46 \%)$.

The ANOVAs performed on all the single diatom species revealed a consistent pattern only for Brachysira neglectissima (Fig. 3; Tab. 2). B. neglectissima was found more abundant within urbanized areas. Other species were either not suitable for analysis (heterogeneous variance, insufficient data) or they provided not significant results (detailed data not showed).

\section{DISCUSSION}

Algal indicators have been recognized as an important tool for evaluating the impact on lakes of human disturbances such as adjacent agricultural and urban development (e.g., Schönfelder et al. 2002; Poulíčková et al. 2004; King et al. 2006). Because diatoms are thought to provide a description of water quality that is 
not achievable from snapshot chemical analyses, their use in monitoring can offset the inconsistency of rapid changes in water chemistry (Smol \& Stoermer 2010).

Tab. 4. Forward selection of the environmental variables following the method proposed by Blanchet et al. (2008). Total, unconstrained and constrained inertia explained by Redundancy Analysis (RDA) performed between diatom assemblages and the significant environmental variables selected in the forward selection. Significance of the whole model is provided. Var. expl $=$ variance explained. $\mathrm{R} 2=$ coefficient of multiple determination; $\mathrm{Cum}=$ cumulated; $\mathrm{Adj}=$ adjusted takes into consideration the number of degrees of freedom. Slo.B $=$ slope at broad scale.

\begin{tabular}{lccccc}
\hline forward selection & R2 & R2Cum & AdjR2Cum & $F$ & $p$ \\
\hline slo.B & 0.154 & 0.154 & 0.116 & 4.015 & 0.002 \\
silica & 0.124 & 0.278 & 0.209 & 3.601 & 0.001 \\
microheterogeneity $^{0} 0.072$ & 0.351 & 0.253 & 2.230 & 0.015 \\
$\mathrm{~N}-N O_{3}$ & 0.060 & 0.411 & 0.287 & 1.950 & 0.025 \\
\hline RDA model & Inertia $\%$ var. expl. & & & \\
\hline Total & 0.169 & & & & \\
Constrained & 0.078 & $45.8 \%$ & & & \\
Unconstrained & 0.092 & $54.2 \%$ & & & \\
\hline significance & $d f$ & Var & $F$ & N.Perm & $\operatorname{Pr}(>F)$ \\
\hline Model & 5 & 0.078 & 3.047 & 999 & 0.001 \\
Residual & 18 & 0.092 & & & \\
\hline
\end{tabular}

Our study provided clear evidence that anthropogenic disturbances affect the diatom assemblages in different ways. In this lake, the presence of different anthropogenic gradients of unequal intensities led to a complex pattern which was revealed by using assemblage metrics of different sensitivities. These results were also important because they provided the ecological setting necessary to individuate the target requested in the Water Framework Directive 2000/60/EC (Council of the European Communities 2000) for Lake Garda.

This study documents for the first time the significant latitudinal gradient concerning the hydrochemistry of near-shore waters, and in particular the importance of nutrients. Even though this snapshot chemical analysis should be verified again in future studies, almost all the assemblage diatom metrics supported the latitudinal gradient. Nutrient concentrations decrease from North to South, probably because of the influence of the Sarca northern inflow. The three main tributaries of the lake supply about $120-150 \mathrm{t}$ of phosphorous per year, $45 \%$ of which is provided by the Sarca River alone (Decet \& Salmaso 1997). In contrast, the difference between nutrient concentrations measured in highly and sparsely urbanized areas was not so marked as to be significant. However, the extent of this difference was not uniform across localities, suggesting different levels of anthropogenic impact along the shoreline (Salmaso et al. 2009). The sewers receiving most of the anthropogenic discharges are not equally efficient around the lake (Salmaso et al. 1997) and this might contribute to the different effects of our experimental factors. Comparing our results on nutrient concentration for the littoral areas to those reported by Salmaso (2009) for the epilimnetic zone $(0-20 \mathrm{~m}$ depth), two interesting main considerations have emerged. Firstly, the extent of nutrient fluctuation over a 17-year period was as great as the spatial variability we measured in a snapshot analysis. The implication of this comparison, assuming a comparable temporal variance, was that any ecological monitoring of the littoral zone should try to separate spatial from temporal variations before attempting to come to significant conclusions or producing relevant management guidelines. Failing to disentangle these two components might lead to completely confounded results. Secondly, the dissolved inorganic nitrogen $\left(\mathrm{DIN}=\mathrm{N}-\mathrm{NO}_{3}+\mathrm{N}-\right.$ $\mathrm{NO}_{2}+\mathrm{N}_{-} \mathrm{NH}_{4}$ ) measured in the littoral areas ranged between 390 and $510 \mu \mathrm{g} \mathrm{L}^{-1}$ whereas that reported by Salmaso (2009) for the epilimnetic zone ranged between 180 and $260 \mu \mathrm{g} \mathrm{L}^{-1}$ (years 1995-2007). This higher DIN for the littoral areas suggested that the point sources represent an important contributor of nutrient inputs into the lake. The higher trophic conditions predicted by the Trophic Index (Hofmann 1994) in comparison to the OECD (1982) classification seem to be consistently justified (see below).

The hypothesis of a higher diversity in the lightly urbanized areas was not accepted. However, because the concentration of nutrients was not significantly different between urbanization levels, this result was not unexpected. As a matter of fact, the negative and significant correlation between diversity and nitrate concentration suggests that diversity is a potential indicator of trophic conditions.

Using the correlation between index scores and the nitrogen content of water, the Hofmann index outperformed that of Kelly et al. Explanations for this result might be reduced to two main categories: the first is related to the different criteria used to elaborate the indices (Hofmann 1994; Kelly et al. 2006), and the second concerns the problem of geographical transferability of species distribution models that are based on niche (e.g., Guisan \& Zimmermann 2000). Since most of the quality indexes infer their evaluation criteria from species distributions gathered in specific regions, their applicability outside the original regions should always be checked. The extent to which an index is transferable across different regions is mostly related to the variability of the realized species niches: the more similar the species niches are among different regions, the more reliable the transferability will be (but see concerns in Guisan \& Zimmerman 2000). The Hofmann index (originally developed for central European lakes), without any calibration and even accounting for an incomplete list of species (Hofmann 1994), seems to provide adequate results in Lake Garda. According to the OECD (1982) classification, Lake Garda is currently oligomesotrophic (Salmaso et al. 2006), a condition that was 
overestimated by the Hofmann Index (mesotrophic and meso-eutrophic). However, it is not uncommon that quality indices applied to littoral species indicate a higher trophic condition than other indices applied to pelagic species (e.g., Komárková \& Marvan 1987). As Eiseltová (1994) suggested, this pattern might be considered as a symptom of the eutrophication process in lakes; this assertion is supported by the steady increase of TP observed in the water column during the last decade in Lake Garda (Salmaso 2005). The monitoring of littoral shores by using epilithic diatoms might represent a useful early-warning tool, particularly effective in cases where there is a diffuse input of nutrients. In our study the Hofmann Index was consistently higher in the highly urbanized areas, even though the extent of this difference was not fully significant ( $p=0.06$; Fig. 3; Tab. 2). More clearly detected by the Hofmann Index was the latitudinal effect, probably as a consequence of the gradient in nutrient concentration (Fig. 3; Tab. 2).

The proportion of endangered taxa included in the Red List might sometimes help in characterizing the environmental conditions of sites (Werum \& LangeBertalot 2004), and has been increasingly used (Cantonati \& Spitale 2009; Angeli et al. 2010). In this study the efficiency of the proportion of Red List taxa in distinguishing between low and high urbanization levels tended to increase when the two levels differed in TP concentration (cfr Fig. 3 and Fig. 2). Many (33\%) of the species recorded were threatened and rare, a proportion that was also in perfect accordance with other studies carried out in other habitats (Werum \& Lange-Bertalot 2004; Cantonati \& Spitale 2009; Angeli et al. 2010). As for quality indices, some form of calibration among regions might improve their efficiency.

The hypothesized high sensitivity of the whole assemblage was supported only when the analysis was restricted to those samples differing in nutrient contents. More interestingly, the latitudinal gradient retained its statistical significance even after controlling for the nutrient gradient. The most trustworthy explanation for this residual effect was the thermal gradient of the water. Remote sensing measurements of surface temperatures (data freely consultable at the web pages of the Department of Geography of the University of Bern) revealed a clear gradient, the extent of which is subject to daily and seasonal variation $\left(\Delta \mathrm{T}\right.$ usually $\left.\geq 3-4{ }^{\circ} \mathrm{C}\right)$. An interesting hypothesis raised by this trend was that the observed difference in the diatom assemblages would result from an asynchronous seasonal cycle of species at different latitudes. On inspecting the temperature data, it appeared that a $\Delta \mathrm{T}=3-4{ }^{\circ} \mathrm{C}$ could desynchronize the North from the South lake by about 1 month. Future studies might test this hypothesis by comparing samples collected at different latitudes and at multiple times.

Knowledge on the autecology of Brachysira neglectissima is still incomplete because of the scarce data that have been collected since its taxonomical description in
2004 (Werum \& Lange-Bertalot 2004). It is known from oligotrophic habitats in the Alps, Germany, and Alaska, often found together with Brachysira neoexilis and, less frequently, with Brachysira vitrea (from both of which it can be clearly differentiated). Given its consistently higher abundance in urbanized areas (Fig. 3; Tab. 2), both as a percentage and in the number of individuals, we might tentatively consider this species as an indicator of anthropogenic impacts in Lake Garda. This assertion might appear to contradict the oligotrophic condition in which the species has been found until now; however, it should be noted that even though the difference in nutrient concentration between low and high urbanization levels was sometimes appreciable (Fig. 2), the trophic condition in general might be still considered oligotrophic. Before we have the necessary evidence for considering this species a reliable indicator of the level of urbanization, this result also needs to be confirmed along a temporal scale. While replicated sampling in space and time might demonstrate the association between species response and urbanization levels, at the moment we are not able to suggest any causal relationships. In fact, none of the environmental variables measured in this study were significantly linked to this species.

In spite of the apparent independence of B. neglectissima from the most common environmental descriptors, the distribution of diatom assemblages was significantly explained by both chemical and physical variables (Tab. 4). A significant proportion of the total variance $(46 \%)$ was explained by four variables. Beyond the expected importance of nitrates and silica (Smol \& Stoermer 2010), more interesting were the significant effect of slope at a broad spatial scale (at shore level) and microheterogeneity. The slope calculated on the first few meters might be directly related to water circulation (and all the connected overturn processes) and ultimately also to the local temperature. Even though we are not aware of other studies reporting this specific effect, this result seems to be a promising topic to be investigated in Lake Garda. Equally interesting was the microheterogeneity (at cms scale), the effect of which was significant for the diatom distribution. During this study we recognized at least three broad classes of heterogeneity: (1) the low heterogeneity of the smooth stones that are particularly abundant in the urbanized areas (Fig. 2), (2) the medium heterogeneity of marlstone-limestone rocks and (3) the high heterogeneity of carbonate rocks characterized by more or less deep karstic-dissolution cavities. It might be argued that these different shapes, regardless of their lithological origin, are able to modulate the conditions of the microhabitat. Recognizing the effect of heterogeneity, along with the problem of the simplification of natural habitats occurring in urbanized areas, suggests that ecologists need a better understanding of how this habitat characteristic affects the distribution of benthic algae in lakes. 


\section{ACKNOWLEDGMENTS}

This work was funded by the University and Scientific Research Department of the Autonomous Province of Trento (ACE-SAP Project - Alpine ecosystems in a changing environment: biodiversity sensitivity and adaptive potential, 2008-2011). The authors would like to thank Fabio Decet and Jacopo Gabrieli (Environmental Agency of the Veneto Region, Dept. of Belluno) for the hydrochemical analyses. This paper was finalized while M.C. was Associate Researcher of the Institute for Ecosystem Study (ISE-CNR; Verbania Pallanza, Italy).

\section{REFERENCES}

Anderson, M.J. 2001. A new method for non-parametric multivariate analysis of variance. Austral Ecology, 26: 32-46.

Angeli, N., M. Cantonati, D. Spitale \& H. Lange-Bertalot. 2010. A comparison between diatom assemblages in two groups of carbonate, lowland springs with different levels of anthropogenic disturbances. Fottea, 10: 115-128.

APHA. 2000. Standard Methods for the Examination of Water and Wastewater $20^{\text {th }}$ ed., APHA, AWWA \& WEF, American Public Health Association, Washington DC.

Barbour, M.T., W.F. Swietlik, S.K. Jackson, D.L. Courtemanch, S.P. Davies \& C.O. Yoder. 2000. Measuring the attainment of biological integrity in the USA: a critical element of ecological integrity. Hydrobiologia, 422/423: 453-464.

Blanchet, F.G., P. Legendre \& D. Borcard. 2008. Forward selection of explanatory variables. Ecology, 89: 2623-2632.

Büsing, N. 1998. Seasonality of phytoplankton as an indicator of trophic status of the large perialpine "Lago di Garda". Hydrobiologia, 369/370: 153-162.

Cantonati, M. \& D. Spitale. 2009. The role of environmental variables in structuring epiphytic and epilithic diatom assemblages in springs and streams of the Dolomiti Bellunesi National Park (south-eastern Alps). Fundam. Appl. Limnol., Arch. Hydrobiol., 174/2: 117-133.

Chiaudani, G. \& G. Premazzi. 1990. Il lago di Garda. Evoluzione trofica e condizioni ambientali attuali. Commissione delle comunità europee, EUR 12925, Lussemburgo: 196 pp.

Council of the European Communities. 2000. Directive $2000 / 60 / \mathrm{EC}$ of the European parliament and of the council of 23 October 2000 establishing a framework for community action in the field of water policy. Official Journal of the European Communities L327: 1-72.

Decet, F. \& N. Salmaso. 1997. Indagini preliminari sulle caratteristiche chimiche dei principali affluenti e dell'emissario del Lago di Garda. Acqua \& Aria, 7: 91-97.

Douglas, M.S.V. \& J.P. Smol. 1995. Periphytic diatom assemblages from high Arctic ponds. J. Phycol., 31: 60-69.

Eiseltová, M. 1994. Restoration of lake ecosystems - a holistic approach. IWRB Publ. 32, Oxford: 202 pp.

Forti, A. 1899. Contributo $2^{\circ}$ alla conoscenza della florula ficologica veronese. La Nuova Notarisia, Serie X: 86-89.

Garbini, A. 1897. Diatomee bentoniche del lago di Garda. Mem. Acc. Verona, Vol. LXXIII Serie III Fascicolo II: 67-71.

Garbini, A. 1899a. Ancora sulle Diatomee bentoniche del lago di Garda. Mem. Acc. Verona, Vol. LXXIV Serie III Fascicolo I: $3-8$.

Garbini, A. 1899b. Alghe neritiche del lago di Garda. La Nuova Notarisia, Serie X: 1-20.

Guisan, A. \& N.E. Zimmermann. 2000. Predictive habitat distribution models in ecology. Ecol. Model., 135: 147-186.

Hofmann, G. 1994. Aufwuchs-Diatomeen in Seen und ihre Eignung als Indikatoren der Trophie. In: H. Lange-Bertalot (Ed.), Bibliotheca Diatomologica, 30: 241 pp.
Kelly, M.G. 2006. Comparison between diatoms and other phytobenthos as indicators of ecological status in streams in northern England. In: Witkowski, A. (Ed.), Proceedings of the $18^{\text {th }}$ International Diatom Symposium. Biopress Bristol: 139-151.

Kelly, M.G., S. Juggins, H. Bennion, A. Burgess, M. Yallop, H. Hirst, L. King, J. Jamieson, R. Guthrie \& B. Rippey. 2006. Use of diatoms for evaluating ecological status in UK freshwaters. Science Report to the UK Environment Agency, Bristol: $171 \mathrm{pp}$.

King, L., G. Clarke, H. Bennion, M. Kelly \& M. Yallop. 2006. Recommendations for sampling littoral diatoms in lakes for ecological status assessments. Journal of Applied Phycology, 18: 15-25.

King, L., P. Barker \& R.I. Jones. 2000. Epilithic algal communities and their relationship to environmental variables in lakes of the English Lake District. Freshwat. Biol., 45 (4): 425-442.

Kirchner, O. 1899. Florura phycologica benacensis. XXXVI. Pubblicazione del Civico Museo di Rovereto: $36 \mathrm{pp}$.

Komárková, J. \& P. Marvan. 1987. The role of algae in the littoral zone of carp ponds. Arch. Hydrobiol., 27: 239-249.

Krammer, K. 1997a. Die cymbelloiden Diatomeen. Teil 1. Allgemeines und Encyonema Part. Bibliotheca Diatomologica, 36: $382 \mathrm{pp}$.

Krammer, K. 1997b. Die cymbelloiden Diatomeen. Teil 2. Encyonema part., Encyonopsis and Cymbellopsis. Bibliotheca Diatomologica, 37: $469 \mathrm{pp}$.

Krammer, K. 2002/2003. Cymbella. / Cymbopleura, Delicata, Navicymbula, Gomphocymbellopsis, Afrocymbella. In: H. Lange Bertalot (Ed.), Diatoms of Europe, Diatoms of the European Inland waters and comparable habitats, 3: 584 pp. / 4: 530 pp. A.R.G. Gantner Verlag, K.G. Ruggell.

Krammer, K. \& H. Lange-Bertalot. 1988. Bacillariophyceae: Bacillariaceae, Epithemiaceae, Surirellaceae. In: H. Ettl, J. Gerloff, H. Heynig \& D. Mollenhauer (Eds), Süßwasserflora von Mitteleuropa, 2/2: $611 \mathrm{pp}$.

Krammer, K. \& H. Lange-Bertalot 1991. Bacillariophyceae: Achnanthaceae, Kritische Ergänzungen zu Achnanthes s.l., Navicula s. str. Gomphonema. In: H. Ettl, J. Gerloff, H. Heynig \& D. Mollenhauer (Eds), Süsswasserflora von Mitteleuropa, 2/4: 437 pp.

Krammer, K. \& H. Lange-Bertalot. 1991. Bacillariophyceae: Centrales, Fragilariaceae, Eunotiaceae. In: H. Ettl, J. Gerloff, H. Heynig \& D. Mollenhauer (Eds), Süßwasserflora von Mitteleuropa, 2/3: $576 \mathrm{pp}$.

Krammer, K. \& H. Lange-Bertalot. 1997. Bacillariophyceae: Naviculaceae. In: H. Ettl, J. Gerloff, H. Heynig \& D. Mollenhauer (Eds), Süßwasserflora von Mitteleuropa, 2/1: $876 \mathrm{pp}$.

Lange-Bertalot, H. 1993. 85 Neue Taxa: und über 100 weitere neu definierte Taxa ergänzend zur Süßwasserflora von Mitteleuropa 2/1-4. Bibliotheca Diatomologica, Band 27: $134 \mathrm{pp}$.

Lange-Bertalot, H. 2001. Navicula sensu stricto, 10 genera separated from Navicula sensu lato, Frustulia. In: LangeBertalot, H. (Ed.), Diatoms of Europe, Diatoms of the European inland waters and comparable habitats, 2: 526 pp A.R.G. Gantner Verlag, K.G. Ruggell.

Lange-Bertalot, H. \& G. Moser. 1994. Brachysira. Monographie der Gattung. Bibliotheca Diatomologica, 29: 212 pp.

Lange-Bertalot, H. \& D. Metzeltin. 1996. Indicators of Oligotrophy: 800 taxa representative of three ecologically distinct lakes types. In: H. Lange-Bertalot (Ed.), Koeltz, Koenigstein. Iconographia Diatomologica, 2: 390 pp.

Lange-Bertalot, H. 1996. Rote Liste der limnischen Kieselalgen (Bacillariophyceae) Deutschlands. Schriftenreihe für Vegetationskunde, 28: 633-677.

Legendre, P. \& E.D. Gallagher. 2001. Ecologically meaningful transformations for ordination of species data. Oecologia, 129: 271-280. 
Legendre, P. \& L. Legendre. 1998. Numerical ecology. Second English edition. Elsevier Science B.V., Amsterdam, 20: $853 \mathrm{pp}$.

Levkov, Z. 2009. Amphora sensu lato. In: H. Lange-Bertalot (Ed.), Diatoms of Europe, Diatoms of the European Inland waters and comparable habitats, 5: 916 pp. A.R.G. Gantner Verlag, K.G. Ruggell.

Lim, D.S.S., C. Kwan \& M.S.V. Douglas. 2001. Periphytic diatom assemblages from Bathurst Island, Nunavut, Canadian High Arctic: an examination of community relationships and habitat preferences. J. Phycol., 37: 379-392.

Magurran, A.E. 2004. Measuring biological diversity. Blackwell Publishing, Oxford: 260 pp.

Mosello, R. \& G. Giussani (Eds). 1997. Evoluzione recente della qualità delle acque dei laghi profondi sudalpini. Documenta Ist. ital. Idrobiol., 61: 228 pp.

OECD. 1982. Eutrophication of waters. Monitoring, assessment and control. Organization for Economic Co-operation and Development, Paris.

Oksanen, J., R. Kindt, P. Legendre, B. O'Hara, G.L. Simpson, P. Solymos, M.H.H. Stevens \& H. Wagner. 2009. vegan: Community Ecology Package. R package version 1.15-2. http://cran.r-project.org/, http://vegan.r-forge.r-project.org/

Poulíčková, A., M. Duchoslav \& M. Dokulil. 2004. Littoral diatom assemblages as bioindicators of lake trophic status: A case study from perialpine lakes in Austria. Eur. J. Phycol., 39: 143-152.

Prygiel, J., B.A. Whitton \& J. Bukowska. 1999. Use of Algae for Monitoring Rivers III. In: J. Prygiel, B.A. Whitton and J. Bukowska (Eds), Agence d'Eau Artois-Picardie, Douai, France: $271 \mathrm{pp}$.

R Development Core Team. 2009. R: a language and environment for statistical computing. Vienna Austria. http:// www.R-project.org.

Reichardt, E. 1997. Taxonomische Revision des Artenkomplexes um Gomphonema pumilum (Bacillariophyceae). Nova Hedwigia, 65: 99-129.

Reichardt, E. 1999. Zur Revision der Gattung Gomphonema. Die Arten um G. affine/insigne, G. angustatum/micropus, G. acuminatum sowie gomphonemoide Diatomeen aus dem Oberoligozän in Böhmen. Iconographia Diatomologica, 8: 203 pp.

Round, F.E. \& L. Bukhtiyarova. 1996. Four new genera based on Achnanthes (Achnanthidium) together with a redefinition of Achnanthidium. Diatom Research, 11: 363-372.

Round, F.E., R.M. Crawford \& D.G. Mann. 1990. The diatoms: biology and morphology of the genera. Cambridge University Press, Cambridge: 758 pp.
Salmaso, N. 2005. Effects of climatic fluctuations and vertical mixing on the interannual trophic variability of Lake Garda, Italy. Limnol. Oceanogr., 50: 553-565.

Salmaso, N. 2010. Long-term phytoplankton community changes in a deep subalpine lake: responses to nutrient availability and climatic fluctuations. Freshwat. Biol., 55: 825-846.

Salmaso, N., F. Decet \& R. Mosello. 1997. Chemical characteristics and trophic evolution of the deep subalpine Lake Garda (Northern Italy). Mem. Ist. ital. Idrobiol., 56: 51-76.

Salmaso, N., A. Boscaini, C. Cappelletti \& F. Ciutti. 2009. Le condizioni di salute del Lago di Garda: aggiornamento dello stato delle conoscenze sui carichi di nutrienti algali e sulle componenti biologiche della zona pelagica e litorale. In: Bertin, F. \& A. Bortoli (Eds), Problematiche ambientali del Lago di Garda: approfondimenti e proposte di risanamento. Libro degli atti. Torri del Benaco. Regione del Veneto \& ANSAC Associazione Nazionale per la Sorveglianza Ambientale e il Controllo, Roma e VeneziaMestre: 49-88.

Salmaso, N., G. Morabito, F. Buzzi, L. Garibaldi, M. Simona, R. Mosello. 2006. Phytoplankton as an indicator of the water quality of the deep lakes south of the Alps. Hydrobiologia, 563: 167-187.

Schönfelder, I., J. Gelbrecht, J. Schönfelder \& C.E.W. Steinberg. 2002. Relationships between littoral diatoms and their chemical environment in northeastern German lakes and rivers. J. Phycol., 38: 66-82.

Schröter, C. \& O. Kirchner. 1896. Die Vegetation des Bodensees. Lindaui.B.: 232 pp.

Stenger-Kovács, C., K. Buczkó, É. Hajnal \& J. Padisák. 2007. Epiphytic, littoral diatoms as bioindicators of shallow lake trophic status: Trophic diatom index for lakes (TDIL) developed for Hungary. Hydrobiologia, 589: 141-154.

Smol, J.P. \& E.F. Stoermer. 2010. The Diatoms. Applications for the Environmental and Earth Sciences. 2nd rev. ed. Cambridge University Press: 686 pp.

Tilman, D., S.S. Kilham \& P. Kilham. 1982. Phytoplankton community ecology: the role of limiting nutrients. Annual Review of Ecology and Systematics, 13: 349-372.

Underwood, A.J. 1997. Experiments in Ecology: Their Logical Design and Interpretation Using Analysis of Variance. Cambridge University Press, NY USA: 504 pp.

Werum, M. \& H. Lange-Bertalot. 2004. Diatoms in Springs from Central Europe and elsewhere under the influence of hydrogeology and anthropogenic impacts. In: LangeBertalot, H. (Ed.), Iconographia Diatomologica. Koeltz, Koenigstein, 13: 417 pp.

Whitton, B.A. \& E. Rott (Eds). 1996. Use of Algae for Monitoring Rivers II. Proceedings of the 2nd European Workshop Innsbruck 1995: 196 pp. 


\section{A $\quad P \quad P \quad E N$ D I X}

NS = Number of samples in which the taxon was found; urb.high $=$ areas at high urbanization; urb.low $=$ areas at low urbanization; $\mathrm{RL}=$ Red List species (Lange-Bertalot 1996), 1 = threatened with extinction, 2 = severely endangered, 3 = endangered, $\mathrm{V}=$ decreasing, $\mathrm{G}=$ presumed endangered, $\mathrm{R}=$ extremely rare, $\mathrm{D}=$ data scarce, $*=$ at present not considered threatened, $* *=$ surely not threatened; $r$ = taxa supposed to be rare on the basis of experience and / or the literature. Value of Hofmann Trophic Index (Hofmann, 1999): $\mathrm{L}=$ trophic location (Lokation), $\mathrm{G}=$ weighting (Gewichtung), \# = not available in Hofmann (1999).

\begin{tabular}{|c|c|c|c|c|c|c|c|c|c|}
\hline & NS & NSurb.high & iNSurb.low & NSnorth & NScentre & NSsouth & RL & $\mathrm{L}$ & G \\
\hline Achnanthidium affine (Kützing) Czarnecki & $24(100 \%)$ & $12(100 \%)$ & $12(100 \%)$ & $8(100 \%)$ & $8(100 \%)$ & $8(100 \%)$ & * & 4.1 & 2 \\
\hline Achd. minutissimum (Kützing) Czarnecki & $24(100 \%)$ & $12(100 \%)$ & $12(100 \%)$ & $8(100 \%)$ & $8(100 \%)$ & $8(100 \%)$ & $* *$ & \# & \\
\hline Achd. neomicrocephalum Lange-Bertalot \& Staab & $6(25 \%)$ & $3(25 \%)$ & $3(25 \%)$ & $1(13 \%)$ & $3(38 \%)$ & $2(25 \%)$ & $\mathrm{R}$ & 1 & 3 \\
\hline Adlafia bryophila (Petersen) Lange-Bertalot & $2(8 \%)$ & $2(17 \%)$ & $0(0 \%)$ & $0(0 \%)$ & $0(0 \%)$ & $2(25 \%)$ & $\mathrm{V}$ & \# & \\
\hline Amphora inariensis Krammer & $9(38 \%)$ & $7(58 \%)$ & $2(17 \%)$ & $5(63 \%)$ & $2(25 \%)$ & $2(25 \%)$ & 3 & & \\
\hline Amph. ovalis (Kützing) Kützing & $1(4 \%)$ & $0(0 \%)$ & $1(8 \%)$ & $0(0 \%)$ & $1(13 \%)$ & $0(0 \%)$ & ** & 4 & 2 \\
\hline Amph. pediculus (Kützing) Grunow & $22(92 \%)$ & $12(100 \%)$ & $10(83 \%)$ & $7(88 \%)$ & $7(88 \%)$ & $8(100 \%)$ & ** & \# & \\
\hline Aneumastus minor (Hustedt) Lange-Bertalot & $1(4 \%)$ & $1(8 \%)$ & $0(0 \%)$ & $0(0 \%)$ & $0(0 \%)$ & $1(13 \%)$ & * & 3.5 & 2 \\
\hline Aneum. stroesei (Østrup) D.G. Mann & $4(17 \%)$ & $2(17 \%)$ & $2(17 \%)$ & $0(0 \%)$ & $1(13 \%)$ & $3(38 \%)$ & 3 & 1.9 & 1 \\
\hline Brachysira lilliana Lange-Bertalot & $11(46 \%)$ & $6(50 \%)$ & $5(42 \%)$ & $1(13 \%)$ & $4(50 \%)$ & $6(75 \%)$ & 2 & & \\
\hline Brach. neglectissima Lange-Bertalot & $18(75 \%)$ & $10(83 \%)$ & $8(67 \%)$ & $6(75 \%)$ & $7(88 \%)$ & $5(63 \%)$ & $\mathrm{D}$ & & \\
\hline Caloneis fontinalis Lange-Bertalot \& Reichardt & $2(8 \%)$ & $1(8 \%)$ & $1(8 \%)$ & $2(25 \%)$ & $0(0 \%)$ & $0(0 \%)$ & $*$ & & \\
\hline Cavinula scutelloides (W. Smith) Lange-Bert. & $1(4 \%)$ & $0(0 \%)$ & $1(8 \%)$ & $0(0 \%)$ & $0(0 \%)$ & $1(13 \%)$ & $\mathrm{V}$ & 4.5 & 3 \\
\hline Cocconeis pediculus Ehrenberg & $22(92 \%)$ & $10(83 \%)$ & $12(100 \%)$ & $8(100 \%)$ & $7(88 \%)$ & $7(88 \%)$ & ** & 4.4 & 3 \\
\hline Cymbella excisa var. angusta Krammer & $24(100 \%)$ & $12(100 \%)$ & $12(100 \%)$ & $8(100 \%)$ & $8(100 \%)$ & $8(100 \%)$ & $*$ & 2.4 & 1 \\
\hline Cymb. helvetica Kützing & $8(33 \%)$ & $3(25 \%)$ & $5(42 \%)$ & $3(38 \%)$ & $4(50 \%)$ & $1(13 \%)$ & $\mathrm{V}$ & 1.7 & 2 \\
\hline Cymb. lanceolata Agardh var. lanceolata & $3(13 \%)$ & $0(0 \%)$ & $3(25 \%)$ & $1(13 \%)$ & $1(13 \%)$ & $1(13 \%)$ & V & 4 & 2 \\
\hline Cymb. lange-bertalotii Krammer & $19(79 \%)$ & $9(75 \%)$ & $10(83 \%)$ & $7(88 \%)$ & $6(75 \%)$ & $6(75 \%)$ & $*$ & 1.7 & 2 \\
\hline Cymb. neoleptoceros Krammer & $21(88 \%)$ & $9(75 \%)$ & $12(100 \%)$ & $7(88 \%)$ & $6(75 \%)$ & $8(100 \%)$ & $*$ & & \\
\hline Cymb. parva (W. Smith) Kirchner & $5(21 \%)$ & $1(8 \%)$ & $4(33 \%)$ & $2(25 \%)$ & $3(38 \%)$ & $0(0 \%)$ & $\mathrm{R}$ & & \\
\hline Cymb. parva var. angusta Krammer & $1(4 \%)$ & $0(0 \%)$ & $1(8 \%)$ & $1(13 \%)$ & $0(0 \%)$ & $0(0 \%)$ & $\mathrm{R}$ & 2.4 & 1 \\
\hline Cymb. parviformis Krammer & $1(4 \%)$ & $0(0 \%)$ & $1(8 \%)$ & $1(13 \%)$ & $0(0 \%)$ & $0(0 \%)$ & $\mathrm{R}$ & & \\
\hline Denticula tenuis Kützing & $11(46 \%)$ & $5(42 \%)$ & $6(50 \%)$ & $4(50 \%)$ & $6(75 \%)$ & $1(13 \%)$ & * & 3 & 1 \\
\hline Diatoma ehrenbergii Kützing & $19(79 \%)$ & $10(83 \%)$ & $9(75 \%)$ & $8(100 \%)$ & $5(63 \%)$ & $6(75 \%)$ & $* *$ & $\#$ & \\
\hline Diat. mesodon (Ehrenberg) Kützing & $1(4 \%)$ & $0(0 \%)$ & $1(8 \%)$ & $1(13 \%)$ & $0(0 \%)$ & $0(0 \%)$ & $*$ & 2 & 2 \\
\hline Diploneis fontium Reichardt \& Lange-Bertalot & $1(4 \%)$ & $0(0 \%)$ & $1(8 \%)$ & $0(0 \%)$ & $0(0 \%)$ & $1(13 \%)$ & G & 2.4 & 2 \\
\hline Encyonema auerswaldii Rabenh. & $17(71 \%)$ & $7(58 \%)$ & $10(83 \%)$ & $6(75 \%)$ & $5(63 \%)$ & $6(75 \%)$ & * & 4.3 & 3 \\
\hline Ency. cespitosum Kützing & $6(25 \%)$ & $2(17 \%)$ & $4(33 \%)$ & $3(38 \%)$ & $1(13 \%)$ & $2(25 \%)$ & ** & 3.7 & 1 \\
\hline Ency. minutum (Hilse ex Rabenh.) D.G. Mann & $1(4 \%)$ & $0(0 \%)$ & $1(8 \%)$ & $0(0 \%)$ & $1(13 \%)$ & $0(0 \%)$ & $\mathrm{R}$ & 2 & 2 \\
\hline Ency.prostratum (Berkeley) Kützing & $2(8 \%)$ & $1(8 \%)$ & $1(8 \%)$ & $1(13 \%)$ & $1(13 \%)$ & $0(0 \%)$ & $*$ & 4.3 & 3 \\
\hline Ency. silesiacum (Bleisch) D.G. Mann & $12(50 \%)$ & $6(50 \%)$ & $6(50 \%)$ & $3(38 \%)$ & $4(50 \%)$ & $5(63 \%)$ & ** & \# & \\
\hline Ency. ventricosum (Agardh) Grunow in A. Schmidt & $6(25 \%)$ & $3(25 \%)$ & $3(25 \%)$ & $2(25 \%)$ & $1(13 \%)$ & $3(38 \%)$ & $*$ & \# & \\
\hline Encyonopsis krammeri Reichardt & $24(100 \%)$ & $12(100 \%)$ & $12(100 \%)$ & $8(100 \%)$ & $8(100 \%)$ & $8(100 \%)$ & $\mathrm{R}$ & & \\
\hline Encs. subminuta Krammer \& Reichard & $24(100 \%)$ & $12(100 \%)$ & $12(100 \%)$ & $8(100 \%)$ & $8(100 \%)$ & $8(100 \%)$ & $*$ & & \\
\hline Epithemia goeppertiana Hilse & $3(13 \%)$ & $1(8 \%)$ & $2(17 \%)$ & $1(13 \%)$ & $1(13 \%)$ & $1(13 \%)$ & $\mathrm{R}$ & \# & \\
\hline Epit. sorex Kützing & $4(17 \%)$ & $2(17 \%)$ & $2(17 \%)$ & $1(13 \%)$ & $0(0 \%)$ & $3(38 \%)$ & ** & 4 & 2 \\
\hline Fallacia subhamulata (Grunow) D. G. Mann & $1(4 \%)$ & $1(8 \%)$ & $0(0 \%)$ & $0(0 \%)$ & $1(13 \%)$ & $0(0 \%)$ & $*$ & \# & \\
\hline Fragilaria capucina ssp. austriaca (Grunow) Lange-Bert. & $24(100 \%)$ & $12(100 \%)$ & $12(100 \%)$ & $8(100 \%)$ & $8(100 \%)$ & $8(100 \%)$ & G & 2.5 & 1 \\
\hline Frag. capucina Desmazières & $2(8 \%)$ & $2(17 \%)$ & $0(0 \%)$ & $0(0 \%)$ & $2(25 \%)$ & $0(0 \%)$ & $* *$ & 4.5 & 3 \\
\hline Frag. distans (Grunow) Bukhtiyarova & $20(83 \%)$ & $12(100 \%)$ & $8(67 \%)$ & $5(63 \%)$ & $7(88 \%)$ & $8(100 \%)$ & $\mathrm{G}$ & & \\
\hline Frag. perminuta (Grunow) Lange-Bertalot & $20(83 \%)$ & $12(100 \%)$ & $8(67 \%)$ & $6(75 \%)$ & $6(75 \%)$ & $8(100 \%)$ & - & 4.2 & 2 \\
\hline Frag. tenuis Agardh & $3(13 \%)$ & $0(0 \%)$ & $3(25 \%)$ & $1(13 \%)$ & $2(25 \%)$ & $0(0 \%)$ & - & & \\
\hline Gomphonema calcareum P.T. Cleve & $14(58 \%)$ & $7(58 \%)$ & $7(58 \%)$ & $5(63 \%)$ & $6(75 \%)$ & $3(38 \%)$ & $\mathrm{V}$ & \# & \\
\hline Gomp. cf. gracile Ehrenberg & $2(8 \%)$ & $1(8 \%)$ & $1(8 \%)$ & $0(0 \%)$ & $1(13 \%)$ & $1(13 \%)$ & $*$ & \# & \\
\hline Gomp. clavatum Ehrenberg & $1(4 \%)$ & $1(8 \%)$ & $0(0 \%)$ & $0(0 \%)$ & $0(0 \%)$ & $1(13 \%)$ & $\mathrm{D}$ & 4.1 & 3 \\
\hline Gomp. elegantissimum Reichardt \& Lange-Bert. & $16(67 \%)$ & $9(75 \%)$ & $7(58 \%)$ & $8(100 \%)$ & $4(50 \%)$ & $4(50 \%)$ & $\mathrm{R}$ & & \\
\hline Gomp. italicum Kützing & $17(71 \%)$ & $9(75 \%)$ & $8(67 \%)$ & $7(88 \%)$ & $4(50 \%)$ & $6(75 \%)$ & $\mathrm{D}$ & & \\
\hline Gomp. lateripunctatum Reichardt \& Lange-Bertalot & $8(33 \%)$ & $4(33 \%)$ & $4(33 \%)$ & $4(50 \%)$ & $2(25 \%)$ & $5(63 \%)$ & $\mathrm{V}$ & 1.8 & 2 \\
\hline Goтp. minutiforme Lange-Bertalot \& Reichardt & $3(13 \%)$ & $2(17 \%)$ & $1(8 \%)$ & $1(13 \%)$ & $0(0 \%)$ & $2(25 \%)$ & $\mathrm{D}$ & & \\
\hline Gomp. minutum (Agardh) Agardh & $9(38 \%)$ & $4(33 \%)$ & $5(42 \%)$ & $3(38 \%)$ & $2(25 \%)$ & $4(50 \%)$ & 3 & 4.5 & 3 \\
\hline Gomp. minutum f. curtum (Hust.) Lange-Bert. \& Reichardt & $3(13 \%)$ & $1(8 \%)$ & $2(17 \%)$ & $2(25 \%)$ & $1(13 \%)$ & $0(0 \%)$ & ** & & \\
\hline Gomp. olivaceum (Hornemann) Brébisson & $5(21 \%)$ & $2(17 \%)$ & $3(25 \%)$ & $2(25 \%)$ & $1(13 \%)$ & $2(25 \%)$ & $* *$ & 4.1 & 2 \\
\hline Gomp. procerum Reichardt \& Lange-Bertalot & $4(17 \%)$ & $3(25 \%)$ & $1(8 \%)$ & $0(0 \%)$ & $0(0 \%)$ & $4(50 \%)$ & 3 & 2 & 2 \\
\hline Gyrosigma acuminatum (Kützing) Rabenh. & $2(8 \%)$ & $1(8 \%)$ & $1(8 \%)$ & $0(0 \%)$ & $0(0 \%)$ & $2(25 \%)$ & $\mathrm{V}$ & 4.5 & 3 \\
\hline Halamphora oligotraphenta (Lange-Bertalot) Levkov & $23(96 \%)$ & $12(100 \%)$ & $11(92 \%)$ & $8(100 \%)$ & $7(88 \%)$ & $8(100 \%)$ & ** & \# & \\
\hline
\end{tabular}


Appendix: Continuation.

\begin{tabular}{|c|c|c|c|c|c|c|c|c|c|}
\hline & NS & NSurb.high & NSurb.low & NSnorth & NScentre & NSsouth & RL & $\mathrm{L}$ & $\mathrm{G}$ \\
\hline Hannaea arcus (Ehrenberg) Patrick & $1(4 \%)$ & $0(0 \%)$ & $1(8 \%)$ & $1(13 \%)$ & $0(0 \%)$ & $0(0 \%)$ & G & & \\
\hline Karayevia clevei (Grunow) Round \& Bukht. & $6(25 \%)$ & $4(33 \%)$ & $2(17 \%)$ & $2(25 \%)$ & $1(13 \%)$ & $3(38 \%)$ & $*$ & 3.5 & 2 \\
\hline Meridion circulare (Grev.) C.A. Agardh var. circulare & $1(4 \%)$ & $1(8 \%)$ & $0(0 \%)$ & $1(13 \%)$ & $0(0 \%)$ & $0(0 \%)$ & $* *$ & 4 & 2 \\
\hline Navicula capitatoradiata Germain & $1(4 \%)$ & $0(0 \%)$ & $1(8 \%)$ & $0(0 \%)$ & $0(0 \%)$ & $1(13 \%)$ & $* *$ & 4.8 & 3 \\
\hline Navi. cryptotenella Lange-Bertalot & $23(96 \%)$ & $12(100 \%)$ & $11(92 \%)$ & $7(88 \%)$ & $8(100 \%)$ & $8(100 \%)$ & $* *$ & & \\
\hline Navi. cryptotenelloides Lange-Bertalot & $24(100 \%)$ & $12(100 \%)$ & $12(100 \%)$ & $8(100 \%)$ & $8(100 \%)$ & $8(100 \%)$ & $* *$ & \# & \\
\hline Navi. radiosa Kützing & $5(21 \%)$ & $4(33 \%)$ & $1(8 \%)$ & $0(0 \%)$ & $0(0 \%)$ & $5(63 \%)$ & $* *$ & \# & \\
\hline Navi. subalpina Reichardt & $24(100 \%)$ & $12(100 \%)$ & $12(100 \%)$ & $8(100 \%)$ & $8(100 \%)$ & $8(100 \%)$ & $\mathrm{V}$ & 2.1 & 1 \\
\hline Navi. tripunctata (O.F. Müller) Bory & $7(29 \%)$ & $4(33 \%)$ & $3(25 \%)$ & $3(38 \%)$ & $1(13 \%)$ & $3(38 \%)$ & $* *$ & 5 & 3 \\
\hline Nitzschia angustata Grunow & $10(42)$ & $6(50 \%)$ & $4(33 \%)$ & $1(13 \%)$ & $5(63 \%)$ & $4(50 \%)$ & $*$ & \# & \\
\hline Nitz. dissipata (Kützing) Grunow var. dissipata & $20(83 \%)$ & $12(100 \%)$ & $8(67 \%)$ & $6(75 \%)$ & $7(88 \%)$ & $7(88 \%)$ & $* *$ & 4.7 & 3 \\
\hline Nitz. lacuum Lange-Bertalot & $18(75 \%)$ & $11(92 \%)$ & $7(58 \%)$ & $6(75 \%)$ & $6(75 \%)$ & $6(75 \%)$ & $*$ & \# & \\
\hline Nitz. sigmoidea (Ehrenberg) W. Smith & $1(4 \%)$ & $1(8 \%)$ & $0(0 \%)$ & $0(0 \%)$ & $1(13 \%)$ & $0(0 \%)$ & $* *$ & 5 & 3 \\
\hline Nitz. sublinearis Hustedt & $13(54 \%)$ & $7(58 \%)$ & $6(50 \%)$ & $2(25 \%)$ & $5(63 \%)$ & $6(75 \%)$ & $*$ & \# & \\
\hline Planothidium delicatulum (Kützing) Round \& Bukht. & $1(4 \%)$ & $1(8 \%)$ & $0(0 \%)$ & $1(13 \%)$ & $0(0 \%)$ & $0(0 \%)$ & $*$ & 5 & 3 \\
\hline Plan. dubium (Grun.) Round \& Bukht. & $3(13 \%)$ & $3(25 \%)$ & $0(0 \%)$ & $2(25 \%)$ & $1(13 \%)$ & $0(0 \%)$ & $*$ & & \\
\hline Plan. frequentissimum (Lange-Bertalot) Lange-Bert. & $4(17 \%)$ & $2(17 \%)$ & $2(17 \%)$ & $0(0 \%)$ & $2(25 \%)$ & $2(25 \%)$ & $* *$ & \# & \\
\hline Pseudostaurosira brevistriata (Grunow) Williams \& Round & $13(54 \%)$ & $9(75 \%)$ & $4(33 \%)$ & $3(38 \%)$ & $4(50 \%)$ & $6(75 \%)$ & $* *$ & & \\
\hline Reimeria sinuata (Gregory) Kociolek \& Stoermer & $2(8 \%)$ & $2(17 \%)$ & $0(0 \%)$ & $2(25 \%)$ & $0(0 \%)$ & $0(0 \%)$ & $* *$ & \# & \\
\hline Staurosirella pinnata (Ehrenberg) Williams \& Round & $6(25 \%)$ & $4(33 \%)$ & $2(17 \%)$ & $1(13 \%)$ & $0(0 \%)$ & $5(63 \%)$ & $* *$ & $\#$ & \\
\hline
\end{tabular}

Received: April 2011

Accepted: May 2011 